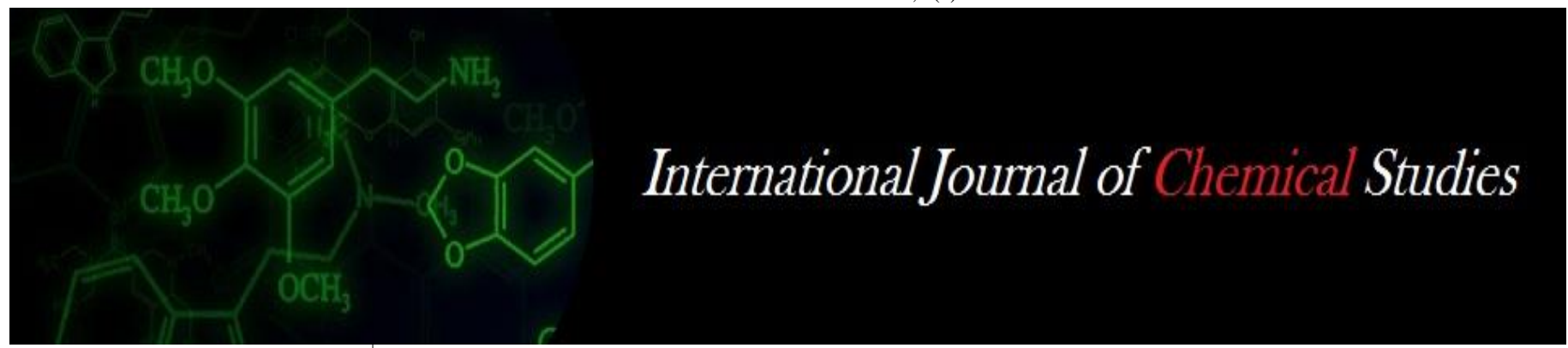

P-ISSN: 2349-8528

E-ISSN: 2321-4902

www.chemijournal.com

IJCS 2020; 8(4): 1910-1913

(C) 2020 IJCS

Received: 13-05-2020

Accepted: 15-06-2020

\section{Neeraj Basir}

Department of Soil Science \&

Agricultural Chemistry, Naini

Agricultural Institute,

Sam Higginbottom University of

Agriculture, Technology \&

Sciences, Prayagraj,

Uttar Pradesh, India

Tarence Thomas

Department of Soil Science \&

Agricultural Chemistry, Naini

Agricultural Institute,

Sam Higginbottom University of

Agriculture, Technology \&

Sciences, Prayagraj,

Uttar Pradesh, India

Narendra Swaroop

Department of Soil Science \&

Agricultural Chemistry, Naini

Agricultural Institute,

Sam Higginbottom University of

Agriculture, Technology \&

Sciences, Prayagraj,

Uttar Pradesh, India

\section{Effect of integrated nutrient management on soil health, growth and yield of wheat (Triticum aestivum L.)}

\author{
Neeraj Basir, Tarence Thomas and Narendra Swaroop
}

DOI: https://doi.org/10.22271/chemi.2020.v8.i4t.9908

\begin{abstract}
A field experiment was conducted during the rabi season 2019-20 to study integrated nutrient management in wheat at the Crop Research Farm of Soil Science Department, Sam Higginbottom University of Agriculture, Technology and Sciences, Prayagraj. The treatments were allocated in Randomized Complete Block Design having nine treatments with three replications. The treatment combination $\mathrm{T}_{9}\left[50 \% \mathrm{RDF}+10 \mathrm{t} \mathrm{FYM} \mathrm{ha}{ }^{-1}+200 \mathrm{~g}\right.$ Azotobacter $10 \mathrm{~kg}^{-1}$ seed] gave the best results with respect to growth and yield parameters, viz., plant height $(89.70 \mathrm{~cm})$, number of tillers $(104.81)$, fresh weight (19.75 g), dry weight (7.27 g), test weight (59.20 g), biological yield (89.13 q ha $\left.{ }^{-1}\right)$ and grain yield $\left(45.20 \mathrm{q} \mathrm{ha}^{-1}\right)$. Combined use of inorganic fertilizers, organic manures and biofertilizers resulted in significant enrichment of soil fertility status. Nitrogen in combination with FYM and Azotobacter resulted in slight decrease in $\mathrm{pH}(7.3)$, electrical conductivity $(0.19)$, organic carbon $(0.56 \%)$ and available nitrogen $\left(287.34 \mathrm{~kg} \mathrm{ha}^{-1}\right)$, phosphorus $\left(29.27 \mathrm{~kg} \mathrm{ha}^{-1}\right)$ and potassium $\left(169.53 \mathrm{~kg} \mathrm{ha}^{-1}\right)$ in the soil.
\end{abstract}

Keywords: Wheat, NPK, Azotobacter, growth, yield, integrated nutrient management, soil properties

\section{Introduction}

The basic concept underlying the principles of integrated nutrient management is the maintenance and possibly improvement of soil fertility for sustaining crop productivity on long term basis. This may be achieved through combined use of all possible sources of nutrients and their scientific management for optimum growth, yield and quality of different crops and cropping systems. Fertilizer is the most indispensable input in crop production. Due to high field to field variability, the possibility of over or under-application of nutrients is very high. Several researchers have highlighted falling productivity and nutrient use efficiency, multi-nutrient deficiencies, high extent of nutrient mining and falling farm income as the consequences of generalized recommendation (Ghosh et al., 2004; Tiwari, 2007) ${ }^{[1,2]}$. Use of farmyard manure (FYM) is a means to combat the ill effects of chemical fertilizers to the soil health and crop residues improve the efficiency of applied fertilizer. On the whole, incorporation of organic manures improves the nutrient content and uptake and also improves soil physical properties (Sial et al., 2007) ${ }^{[3]}$. Among biofertilizers, Azotobacter strains play a key role in the nitrogen cycle in nature that binds atmospheric nitrogen inaccessible to plants and releasing it in the form of ammonium ions available to plants in the soil (Dilworth et al., 1988). Uttar Pradesh is the largest producer of wheat in the country and hence it is Uttar Pradesh that can provide sufficient production of wheat to feed the increasing demand of the country. In this light, the present investigation was conducted to study the benefits of integrated nutrient management on wheat.

\section{Materials and Methods}

The experiment was conducted at Crop Research Farm, Department of Soil Science and Agricultural Chemistry, Naini Agricultural Institute, Sam Higginbottom University of Agriculture, Technology and Sciences, Prayagraj, Uttar Pradesh. The experiment was laid out in randomized block design with nine treatments and three replications (Table 1). The treatments consisted of three levels of RDF levels, i.e. $0 \%, 25 \%$ and $50 \%$, three levels of organic manure, i.e. FYM @ $0 \mathrm{t} \mathrm{ha}^{-1}, 5 \mathrm{tha}^{-1}$ and $10 \mathrm{t} \mathrm{ha}^{-1}$ and three levels of biofertilizer, i.e.
Neeraj Basir

Department of Soil Science \&

Agricultural Chemistry, Naini

Agricultural Institute,

Sam Higginbottom University of

Agriculture, Technology \&

Sciences, Prayagraj,

Uttar Pradesh, India 
Azotobacter@0 g $10 \mathrm{~kg}^{-1}$ seed, $100 \mathrm{~g} 10 \mathrm{~kg}^{-1}$ seed and $200 \mathrm{~g}$ $10 \mathrm{~kg}^{-1}$ seed. The crop variety used was Shriram Super 252, a fast growing variety.

The soil of experimental area belonged to the order inceptisol and had sandy loam texture. It was alkaline in reaction (7.6), had non-saline electrical conductivity $\left(0.18 \mathrm{dSm}^{-1}\right)$, medium organic carbon content $(0.45 \%)$, low available nitrogen (271.30 $\left.\mathrm{kg} \mathrm{ha}^{-1}\right)$, available phosphorus $\left(24.50 \mathrm{~kg} \mathrm{ha}^{-1}\right)$ and available potassium $\left(150.60 \mathrm{~kg} \mathrm{ha}^{-1}\right)$. The recommended dose of fertilizers i.e. nitrogen, phosphorus and potassium were 120:60:60 kg ha-1.

Well-decomposed farmyard manure was used as organic manure source and was applied a day prior to sowing. Nitrogen was applied through urea $(46 \% \mathrm{~N})$ in two splits, half being applied as basal dose and the other half at tillering stage. Phosphorus was applied through diammonium phosphate $\left(46 \% \quad \mathrm{P}_{2} \mathrm{O}_{5}\right)$ and potassium through muriate of potash $\left(60 \% \mathrm{~K}_{2} \mathrm{O}\right)$ both at the time of sowing. Seed treatment of Azotobacter was used as the biofertilizer source. Integration of all the sources was done as per treatment. Selected growth and yield parameters were observed.

Soil sample analysis was done before sowing and after harvest. The methods used for estimation were digital $\mathrm{pH}$ meter (Jackson, 1958) for $\mathrm{pH}$, digital EC meter (Wilcox, 1950) [6] for electrical conductivity, alkaline permanganate method (Subbiah and Asija, 1956) ${ }^{[7]}$ for available nitrogen, rapid titration method (Walkley and Black, 1947) for organic carbon, colorimetric method (Olsen et al., 1954) ${ }^{[9]}$ for phosphorus and flame photometer method (Toth and Prince, 1949) ${ }^{[10]}$ for potassium.

\section{Results and Discussion}

The combined application of farmyard manure, NPK fertilizers and Azotobacter yielded beneficial results in the optimum combinations. All the treatment combinations showed superiority over the control (Table 2). The plant height was recorded minimum with $\mathrm{T}_{3}\left(5 \mathrm{t} \mathrm{FYM} \mathrm{ha}^{-1}+100 \mathrm{~g}\right.$ Azotobacter $10 \mathrm{~kg}^{-1}$ seed) and $\mathrm{T}_{5}\left(10 \mathrm{t} \mathrm{FYM} \mathrm{ha} \mathrm{F}^{-1}+200 \mathrm{~g}\right.$ Azotobacter $10 \mathrm{~kg}^{-1}$ seed) treatments both of which had $0 \%$ RDF incorporated. The highest plant height of $93.24 \mathrm{~cm}$ was observed in treatment $\mathrm{T}_{8}\left(50 \% \mathrm{RDF}+10 \mathrm{t} \mathrm{ha}^{-1} \mathrm{FYM}\right)$ at maturity and was found to be significant. The increase in plant height may be attributed to increase in the amount of growth substances with increased nitrogen supply. Similar results were reported by Singh et al. (2011) ${ }^{[11]}$. Number of tillers per meter row length also showed similar trends as in plant height with maximum number 106.09 being attained in $\mathrm{T}_{8}$. Similar findings were reported by Singh et al. (2018) ${ }^{[12]}$.

The maximum fresh weight, $19.27 \mathrm{~g} \mathrm{plant}^{-1}$ of wheat was recorded with $\mathrm{T}_{9}$ treatment $\left(50 \% \mathrm{RDF}+10 \mathrm{tha}^{-1} \mathrm{FYM}+200\right.$ $\mathrm{g}$ Azotobacter $10^{-1} \mathrm{~kg}$ seed) followed by $\mathrm{T}_{8}$. The minimum fresh weight, $12.97 \mathrm{~g}$ plant $^{-1}$ was recorded in the control. The results were found to be significant and similar findings were reported by Singh et al. (2013) ${ }^{[13]}$. Similar trends were witnessed in case of test weight $(\mathrm{g})$ of 1000 seeds per treatment with $59.20 \mathrm{~g}$ as maximum found in $\mathrm{T}_{9}$ treatment. An increased test weight may be attributed to improvement in physical condition of the soil by added organic matter, FYM that helped in optimum translocation of nutrients to the plants. The finding was in line with Desai et al. (2015) ${ }^{[14]}$.

The maximum biological yield was found in $\mathrm{T}_{9}$ treatment which was $89.13 \mathrm{q} \mathrm{ha}^{-1}$. The minimum biological yield of $84.23 \mathrm{q} \mathrm{ha}^{-1}$ was obtained in the control, $\mathrm{T}_{1}$ and the results were significant. The increase in biological yield may be attributed to the increase in grain and straw yields. Similar findings were reported by Singh et al. (2018) ${ }^{[12]}$. The maximum grain yield was found in $\mathrm{T}_{9}$ treatment which was $45.20 \mathrm{q} \mathrm{ha}^{-1}$. The grain yield of $\mathrm{T}_{8}$ treatment was $37.53 \mathrm{q} \mathrm{ha}^{-1}$ and of $\mathrm{T}_{6}\left(25 \% \mathrm{RDF}+5 \mathrm{tha}^{-1} \mathrm{FYM}+100 \mathrm{~g}\right.$ Azotobacter $10^{-1}$ $\mathrm{kg}$ seed) treatment was $37.46 \mathrm{q} \mathrm{ha}^{-1}$ which were at par with each other. The minimum grain yield of $34.06 \mathrm{q} \mathrm{ha}^{-1}$ was obtained in the control, $\mathrm{T}_{1}$ and the results were significant. The increased supply of NPK fertilizers, FYM and Azotobacter and increased nutrient uptake improved the grain and straw yields by stimulating the rate of various physiological processes. Similar findings were reported by Singh et al. (2011) ${ }^{[11]}$. The maximum harvest index was recorded in $\mathrm{T}_{9}$ treatment which was $50.71 \%$ and the lowest harvest index $40.13 \%$ was obtained in $\mathrm{T}_{7}(50 \% \mathrm{RDF}+10 \mathrm{t}$ ha $^{-1}$ FYM) treatment.

In comparison to pre-sowing soil sample, $\mathrm{pH}$ value (Table 3) in most of the treatments was reduced. The maximum decrease in soil $\mathrm{pH}$ was recorded in $\mathrm{T}_{9}$ and $\mathrm{T}_{8}$ treatment which recorded a value of 7.39 and 7.37 respectively. The reduction in soil $\mathrm{pH}$ may be attributed to nitrification process in the soil due to ammonium in nitrogenous fertilizers which increases the acidifying potential and reduces $\mathrm{pH}$. Similar trends were observed in electrical conductivity values which recorded a maximum decreased value of $0.19 \mathrm{dSm}^{-1}$ in $\mathrm{T}_{9}$ treatment and $0.22 \mathrm{dSm}^{-1}$ in $\mathrm{T}_{8}$ treatment. These findings were in close conformity with the findings of Yadav et al. (2017).

In comparison to the initial value, the value of available nitrogen in the treatments incorporated with fertilizers was increased. The maximum value of available nitrogen in soil was recorded with integration of $50 \% \mathrm{RDF}+$ farmyard manure@10 t ha ${ }^{-1}+$ Azotobacter@200 g 10-1 kg seed which recorded a value of $287.34 \mathrm{~kg} \mathrm{ha}^{-1}$. The minimum value of available nitrogen among treatments, $260.76 \mathrm{~kg} \mathrm{ha}^{-1}$ was recorded in the control. Similar trends were observed in case of available phosphorus and potassium with maximum value of phosphorus increase being $29.27 \mathrm{~kg} \mathrm{ha}^{-1}$ and that of potassium being $169.53 \mathrm{~kg} \mathrm{ha}^{-1}$. These findings were in close conformity with the findings of Pandey et al. (2009) ${ }^{[16]}$. The integration of $50 \% \mathrm{RDF}+$ farmyard manure @ $10 \mathrm{t} \mathrm{ha}^{-1}+$ Azotobacter@200 g 10 $10^{-1} \mathrm{~kg}$ seed also improved the organic matter content. The value of organic carbon in soil increased with an increase in the dose of FYM applied as organic matter and its beneficial interaction with inorganic fertilizers and biofertilizers. These findings were in close conformity with the findings of Hemalatha et al. (2013) ${ }^{[17]}$.

Table 1: Experimental treatment combinations of integrated nutrient management

\begin{tabular}{|c|c|}
\hline Treatment & Treatment combinations \\
\hline $\mathrm{T}_{1}$ & Control \\
\hline $\mathrm{T}_{2}$ & $\mathrm{~N}_{30} \mathrm{P}_{15} \mathrm{~K}_{15} \mathrm{~kg} \mathrm{ha}^{-1}$ \\
\hline $\mathrm{T}_{3}$ & $5 \mathrm{t} \mathrm{FYM} \mathrm{ha}^{-1}+100 \mathrm{~g}$ Azotobacter $10 \mathrm{~kg}^{-1}$ seed \\
\hline $\mathrm{T}_{4}$ & $\mathrm{~N}_{30} \mathrm{P}_{15} \mathrm{~K}_{15} \mathrm{~kg} \mathrm{ha}^{-1}+5 \mathrm{t} \mathrm{FYM} \mathrm{ha}^{-1}$ \\
\hline $\mathrm{T}_{5}$ & $10 \mathrm{t} \mathrm{FYM} \mathrm{ha}^{-1}+200 \mathrm{~g}$ Azotobacter $10 \mathrm{~kg}^{-1}$ seed \\
\hline $\mathrm{T}_{6}$ & $\mathrm{~N}_{30} \mathrm{P}_{15} \mathrm{~K}_{15} \mathrm{~kg} \mathrm{ha}^{-1}+5 \mathrm{t} \mathrm{FYM} \mathrm{ha}^{-1}+100 \mathrm{~g}$ Azotobacter $10 \mathrm{~kg}^{-1}$ seed \\
\hline $\mathrm{T}_{7}$ & $\mathrm{~N}_{60} \mathrm{P}_{30} \mathrm{~K}_{30} \mathrm{~kg} \mathrm{ha}^{-1}$ \\
\hline
\end{tabular}




\begin{tabular}{|c|c|}
\hline $\mathrm{T}_{8}$ & $\mathrm{~N}_{60} \mathrm{P}_{30} \mathrm{~K}_{30} \mathrm{~kg} \mathrm{ha}^{-1}+10 \mathrm{t} \mathrm{FYM} \mathrm{ha}^{-1}$ \\
\hline $\mathrm{T}_{9}$ & $\mathrm{~N}_{60} \mathrm{P}_{30} \mathrm{~K}_{30} \mathrm{~kg} \mathrm{ha}^{-1}+10 \mathrm{tFYM} \mathrm{ha}^{-1}+200 \mathrm{~g}$ Azotobacter $10 \mathrm{~kg}^{-1}$ seed \\
\hline
\end{tabular}

Table 2: Effect of integrated nutrient management on growth and yield of wheat

\begin{tabular}{|c|c|c|c|c|c|c|c|c|}
\hline Treatments & $\begin{array}{l}\text { Plant height } \\
(\mathrm{cm})\end{array}$ & $\begin{array}{l}\text { Number of tillers } \\
\mathbf{m}^{-2} \text { row length }\end{array}$ & $\begin{array}{c}\text { Fresh } \\
\text { weight }(g)\end{array}$ & $\begin{array}{c}\text { Test weight } \\
\text { (g) }\end{array}$ & $\begin{array}{c}\text { Biological yield } \\
\left.(\mathbf{q ~ h a})^{-1}\right)\end{array}$ & $\begin{array}{c}\text { Grain yield } \\
\left(\mathbf{q} \text { ha }^{-1}\right)\end{array}$ & \begin{tabular}{|c|} 
Straw yield \\
$\left(\mathbf{q}\right.$ ha $\left.^{-1}\right)$
\end{tabular} & $\begin{array}{c}\text { Harvest } \\
\text { index }(\%)\end{array}$ \\
\hline $\mathrm{T}_{1}$ & 91.92 & 100.54 & 12.97 & 53.53 & 84.23 & 34.90 & 49.33 & 41.43 \\
\hline $\mathrm{T}_{2}$ & 87.92 & 99.09 & 14.17 & 55.93 & 85.93 & 35.98 & 49.95 & 41.87 \\
\hline $\mathrm{T}_{3}$ & 92.03 & 102.00 & 15.60 & 54.07 & 85.07 & 35.93 & 49.14 & 42.23 \\
\hline $\mathrm{T}_{4}$ & 91.23 & 103.90 & 19.03 & 55.13 & 85.13 & 36.20 & 48.93 & 42.52 \\
\hline $\mathrm{T}_{5}$ & 89.98 & 102.72 & 15.80 & 54.33 & 84.33 & 34.33 & 50.00 & 40.71 \\
\hline $\mathrm{T}_{6}$ & 92.61 & 101.63 & 18.37 & 55.27 & 86.27 & 37.46 & 48.81 & 43.42 \\
\hline $\mathrm{T}_{7}$ & 91.82 & 102.27 & 18.41 & 56.20 & 87.53 & 35.13 & 52.40 & 40.13 \\
\hline $\mathrm{T}_{8}$ & 93.24 & 106.09 & 19.27 & 57.47 & 87.47 & 37.53 & 49.94 & 42.91 \\
\hline $\mathrm{T}_{9}$ & 89.70 & 104.81 & 19.75 & 59.20 & 89.13 & 45.20 & 43.93 & 50.71 \\
\hline F-test & $\mathrm{S}$ & $\mathrm{S}$ & $\mathrm{S}$ & $\mathrm{S}$ & $\mathrm{S}$ & $\mathrm{S}$ & $\mathrm{S}$ & NS \\
\hline $\operatorname{SEm}( \pm)$ & 2.13 & 0.17 & 1.01 & 1.4 & 1.4 & 1.4 & 1.41 & 0.45 \\
\hline $\mathrm{CD}$ at $5 \%$ & 6.25 & 0.49 & 2.97 & 4.12 & 4.12 & 4.12 & 4.12 & - \\
\hline
\end{tabular}

Table 3: Effect of integrated nutrient management on soil properties

\begin{tabular}{|c|c|c|c|c|c|c|}
\hline Treatments & $\mathbf{p H}$ & $\begin{array}{c}\text { Electrical } \\
\text { Conductivity }\left(\mathrm{dSm}^{-1}\right) \\
\end{array}$ & $\begin{array}{c}\text { Organic carbon } \\
(\%)\end{array}$ & \begin{tabular}{|c}
$\begin{array}{c}\text { Available nitrogen } \\
\left(\mathrm{kg} \mathrm{ha}^{-1}\right)\end{array}$ \\
\end{tabular} & Available phosphorus $\left(\mathrm{kg} \mathrm{ha}^{-1}\right)$ & \begin{tabular}{|c|}
$\begin{array}{c}\text { Available potassium } \\
\left(\mathrm{kg} \mathrm{ha}^{-1}\right)\end{array}$ \\
\end{tabular} \\
\hline $\mathrm{T}_{1}$ & 7.69 & 0.25 & 0.51 & 260.76 & 24.13 & 162.60 \\
\hline $\mathrm{T}_{2}$ & 7.66 & 0.25 & 0.52 & 278.29 & 25.93 & 164.93 \\
\hline $\mathrm{T}_{3}$ & 7.64 & 0.24 & 0.53 & 260.71 & 24.07 & 165.27 \\
\hline $\mathrm{T}_{4}$ & 7.57 & 0.24 & 0.53 & 274.75 & 25.27 & 166.06 \\
\hline $\mathrm{T}_{5}$ & 7.44 & 0.25 & 0.54 & 272.22 & 24.33 & 165.17 \\
\hline $\mathrm{T}_{6}$ & 7.49 & 0.24 & 0.54 & 279.03 & 25.67 & 167.43 \\
\hline $\mathrm{T}_{7}$ & 7.37 & 0.23 & 0.53 & 285.34 & 26.20 & 167.73 \\
\hline $\mathrm{T}_{8}$ & 7.37 & 0.22 & 0.56 & 282.41 & 27.53 & 169.03 \\
\hline $\mathrm{T}_{9}$ & 7.39 & 0.19 & 0.56 & 287.34 & 29.27 & 169.53 \\
\hline F-test & $\mathrm{S}$ & $\mathrm{S}$ & $\mathrm{S}$ & $\mathrm{S}$ & $\mathrm{S}$ & $\mathrm{S}$ \\
\hline SEm ( \pm$)$ & 0.12 & 0.01 & 0.03 & 4.51 & 1.60 & 2.71 \\
\hline CD at $5 \%$ & 0.34 & 0.04 & 0.08 & 13.25 & 4.71 & 7.96 \\
\hline
\end{tabular}

\section{Conclusion}

Wheat crop supplied with a combined application of $\mathrm{N}_{60} \mathrm{P}_{30} \mathrm{~K}_{30} \mathrm{~kg} \mathrm{ha}^{-1}+10$ t FYM ha ${ }^{-1}+200 \mathrm{~g}$ Azotobacter $10 \mathrm{~kg}^{-}$ 1 seed gave the best results in terms of important growth parameters and yield $\left(45.20 \mathrm{q} \mathrm{ha}^{-1}\right)$. The important physical and chemical properties of soil also improved significantly under this treatment. The benefits of incorporation of integrated nutrient were evident over the control and other treatments without integration. So, it was concluded that wheat crop should be supplied with FYM @ $10 \mathrm{t} \mathrm{ha}^{-1}$ with soil enrichment of $50 \% \mathrm{RDF}$ and biofertilizer inoculation of Azotobacter @200 g $10 \mathrm{~kg}^{-1}$ seed to achieve high productivity in the alluvial soils of Prayagraj with sandy loam texture.

\section{References}

1. Ghosh PK, Bandhopadhyay KK, Mishra AK, Subba RA. Balanced fertilization for maintaining soil health and sustainable agriculture. Fertilizer News. 2004; 49(4):1324.

2. Tiwari KN. Reassessing the role of fertilizers in maintaining food, nutrition and environmental security. Indian Journal of Fertiliser. 2007; 3(1):33-48, 51-52.

3. Sial RA, Chaudhary EH, Hussain S, Naveed M. Effect of organic manure and chemical fertilizer on grain yield of maize in rain-fed area. Soil and Environment. 2007; 26(2):130-133.

4. Dilworth MJ, Eady RR, Eldridge ME. The vanadium nitrogenase of Azotobacter chroococcum reduction of acetylene and ethylene to ethane. Biochem. J. 1988; 249(3):745-751.
5. Jackson ML. Soil chemical analysis. Prentice Hall of India Pvt. Ltd., New Delhi. 1967; 38:226.

6. Wilcox LV. Electrical conductivity. American Water Work Association Journal. 1950; 42:775-776.

7. Subbiah BV, Asija GL. A rapid procedure for the estimation of available nitrogen in soils. Current Science, 1956; 25:259-260.

8. Walkley A, Black CA. An examination of different methods for determining soil organic matter and a proposed modification of the chromic acid titration method. Soil Science. 1934; 37:29-38.

9. Olsen SR, Cole CV, Watanable FS, Dean LA. Estimation of available phosphorus in soil by extraction with sodium bicarbonate, USDA, Circular, 1954; 939:1-19.

10. Toth SJ, Prince AL. Estimation of cation exchange capacity and exchangeable $\mathrm{Ca}, \mathrm{K}$ and $\mathrm{Na}$ content of soil by flame photometer technique. Soil Science. 1949; 67:439-445.

11. Singh CH, Sharma PK, Kishor P, Mishra PK, Singh AP, Verma $\mathrm{R}$ et al. Impact of integrated nutrient management on growth, yield and nutrient uptake by wheat (Triticum aestivum L.). Asian Journal of Agricultural Research, 2011; 5(1):76-42.

12. Singh G, Kumar S, Sidhu GS, Kaur R. Effect of integrated nutrient management on yield of wheat (Triticum aestivum L.) under irrigated conditions. International Journal of Chemical Studies. 2018; 6(2):904-907.

13. Singh V, Singh SP, Singh S, Shivay YS. Growth, yield and nutrient uptake by wheat (Triticum aestivum) as 
affected by biofertilizers, FYM and nitrogen. Indian Journal of Agricultural Sciences. 2013; 83(3):331-334.

14. Desai HA, Dodia IN, Desai CK, Patel MD. and Patel, H.K. Integrated nutrient management in wheat (Triticum aestivum L.). Trends in Biosciences. 2015; 8(2):472-475.

15. Yadav A, Kumar A, Prakash V, Kumar N, Tiwari A, Yadav RK. Effect of integrated nutrient management on soil properties, yield attributes and yield of wheat (Triticum aestivum L.). International Journal of Current Microbiology and Applied Sciences. 2017; 6(10):225228.

16. Pandey IB, Dwivedi DK, Pandey RK. Integrated nutrient management for sustaining wheat (Triticum aestivum) production under late sown condition. Indian Journal of Agronomy. 2009; 54(3):306-309

17. Hemalatha $\mathrm{S}$, Chellamuthu S. Impacts of long term fertilization on soil nutritional quality under finger millet:maize cropping sequence. Journal of Environmental Research and Development. 2013; 7(4A):1571-1576. 